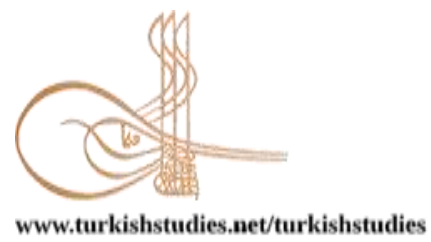

Turkish Studies

\title{
Kentsel Dönüşüm Sürecindeki Gecekondu Bölgelerinde Ortaya Çıkan Toplumsal Sorunlar: Sarıyer-Derbent Mahallesi Örneği*
}

\author{
Social Problems Occurred in Slums in Urban Transformation Process: Sarlyer-Derbent \\ Neighborhood Sample
}

\author{
Simge Altıparmak ${ }^{* *}$ - Meyrem Tuna Uysal ${ }^{* * *}$
}

\begin{abstract}
With migration from The Country side to the city, the continuous increase of the population in cities has led to significant changes in the economic, political and socio-cultural structure of the city. The inability of cities to find solutions to problems such as unplanned population, housing and infrastructure has led to the emergence of slums. The unplanned realization of urbanization, the lack of zoning laws and the inability to evaluate public lands rationally led to the distorted urbanization of urban centers and urban transformation practices came to the fore in the process. As a matter of fact, although these practices have positive aspects such as offering new living spaces to individuals, improving living conditions and eliminating the low quality of the residences, it has also caused many economic and social problems to be expressed negatively. In this study, it is aimed to identify the problems that arise in the slums in the urban transformation process and their social reflections. Therefore, the study focuses on the social dimension of urban transformation and how the problems faced by individuals living in slums planned to implement urban transformation are reflected in their lives. The study is a survey. According to this study, starting from the example of Sariyer Derbent District, the views of the people in the slums about urban transformation and the problems that emerged in this process were discussed. In line with the data obtained from the area, the social effects of urban transformation problems are tried to be explained. As a result of the study, it was determined that the urban transformation process affects the people of Derbent Mahallesi economically and socioculturally, and the emerging problems differentiate the neighborhood people's behavior in supporting urban transformation projects.
\end{abstract}

Structured Abstract: Introduction: Industrialization and migration from village to city, along with the uncontrolled growth of cities that receive intensive migration caused the emergence of an unhealthy urbanization process. In this process, due to the intensive migration to the cities, the migrants found the

\footnotetext{
* Bu makale, Dr. Öğr. Üyesi Meyrem Tuna Uysal danışmanlığında Simge Altıparmak tarafindan hazırlanan, Gecekondu Mahallelerinde Kentsel Dönüşüm Sorunlart ve Toplumsal Yansımaları: Sartyer Derbent Mahallesi Örneği isimli yüksek lisans tezinden üretilmiştir. (Süleyman Demirel Üniversitesi, Sosyal Bilimler Enstitüsü, Isparta, 2019).

** Bilim Uzmanı, Süleyman Demirel Üniversitesi, Sosyal Bilimler Enstitüsü, Sosyoloji Anabilim Dalı. Master of Science, Suleyman University, Institute of Social Sciences, Department of Sociology. ORCī́ 0000-0001-7358-800X simgealtiparmak.91@ hotmail.com *** Dr. Öğr. Üyesi, Süleyman Demirel Üniversitesi, Fen-Edebiyat Fakültesi, Sosyoloji Bölümü. Asst. Prof. Dr., Suleyman Demirel University, Faculty of Arts and Sciences, Department of Sociology. ORCID 0000-0001-8910-8058 meyremtuna@sdu.edu.tr
}

Cite as/ Atıf: Altıparmak, S., Tuna Uysal, M. (2020). Kentsel dönüşüm sürecindeki gecekondu bölgelerinde ortaya çıkan toplumsal sorunlar: Sarıyer-Derbent Mahallesi örneği. Turkish Studies, 15(5), 2637-2651. https://dx.doi.org/10.7827/TurkishStudies.43939

Received/Geliș: 02 June/Haziran 2020

Accepted/Kabul: 25 August/Ağustos 2020

Copyright $($ ) MDE, Turkey

Checked by plagiarism software

Published/Yayın: 31 August/Ağustos 2020

CC BY-NC 4.0 
solution to the settlement and housing problem by making their own slums. Therefore, the formation of slum areas around the city centers has led to uncontrolled and uncontrolled construction in these areas.

With the infrastructure and socio-economic problems caused by the uncontrolled and uncontrolled growth of cities, and the increasing increase in slums, this situation results in the intervention of cities through urban transformation practices. As a matter of fact, such interventions in the city without regard to the demographic, socio-cultural and economic characteristics of individuals living in urban areas cause many problems to occur. Although these practices initially set positive goals such as eliminating low-quality housing, creating a sustainable urban environment and raising the living standards of the urban poor, it is observed that it also leads to many economic and social problems that can be considered negative.

\section{Purpose}

In this study, it is aimed to identify the problems that arise in slums during the urban transformation process and their social repercussions. Accordingly, the 'urban transformation process experienced, although the process of urban transformation affects the people of Derbent District economically and socio-culturally, the social problems experienced in this process differentiate the behavior of the people of the neighborhood to support urban transformation'.

In order to prevent or minimize the problems that arise in the urban transformation process, it is needed to carry out academic studies taking into account the socio-cultural and economic characteristics of individuals living in transformation areas. This study is important for the relevant institutions and organizations to contribute to producing new policies that are more suitable for social reality and needs.

\section{Method}

The study is a survey of studies conducted on selected sample from the universe, which covers large social groups. The universe of the research is made up of individuals living in derbent district of Istanbul / Sariyer district. Accordingly, the universe of the study consists of a total of 6,186 people living in derbent neighborhood. The sample that will represent the universe is calculated by simple random sampling technique and the sample size is set to 365. A survey form was prepared to identify the problems created by urban transformation in slums in order to apply it to the sample group representing the main mass. The findings of the study are limited to the time frame of the study and the selected sample. The data obtained were analyzed in a computer environment using the statistical program suitable for social science

\section{Results}

In the study, the problems associated with the urban transformation project, which has been raised about the neighborhoods of the people living in Derbent Neighborhood, and the social repercussions of these problems are tried to be identified. When the study is taken in line with field data, it is seen that the sample group has a negative meaning to urban transformation. Those interviewed highlight issues such as annuities, the destruction of poor areas and inequality between poor and wealthy communities when defining urban transformation. In addition, with urban transformation, positive views such as the renewal of their homes, the ownership of new living spaces and the rise of life expectancy; On the other hand, they are concerned about the damage of neighborhood culture and neighborly relations

The people of Derbent district think that urban transformation will bring a bad future to the neighborhood and the neighborhood in its current form. It has been determined that they will not approve this project if they reencounter a project similar to the planned urban transformation project in relation to the neighborhood where they live. In addition, the experiences of those interviewed related to urban transformation have reached a reactive point regarding the concept of "urban transformation" due to the problems they experience in particular. As a matter of fact, according to the information obtained from field data and observations made during the research, it is understood that the idea of urban transformation of the people of the neighborhood is more opposed to the way urban transformation is implemented than itself. Therefore, the people of Derbent District express a "on-site transformation" request, which in general takes into account their own expectations and does not require them to leave the neighborhood. Accordingly, the need to better analyze the public's expectations in the design of urban transformation policies and planned projects. 
As a result, the urban transformation process negatively affects the people of Derbent District economically and socio-culturally, and the social problems experienced in this process differentiate the behavior of the people of the neighborhood to support urban transformation.

Keywords: Urbanization, Migration, Slum, Urban Transformation Social Problems.

Öz: Kırdan kente göçle birlikte kentlerde nüfusun sürekli olarak artması, kentin ekonomik, siyasal ve sosyokültürel yapısında önemli değişimleri beraberinde getirmiştir. Plansız artan nüfus, konut ve alt yap1 gibi sorunlara kentlerin çözüm bulamaması gecekondulaşmanın ortaya çıkmasına neden olmuştur. Kentleşmenin plansız şekilde gerçekleşmesi, imar yasalarının yetersizliği ve kamu arazilerinin rasyonel şekilde değerlendirilememesi, kent merkezlerinin çarpık kentleşmesine yol açmış ve bu süreçte kentsel dönüşüm uygulamaları ön plana çıkmıştır. Nitekim bu uygulamaların, bireylere yeni yaşam alanları sunma, yaşam şartlarını iyileştirme ve konutlardaki kalite düşüklügünü ortadan kaldırma gibi olumlu yönleri bulunsa da olumsuz olarak ifade edilecek birçok ekonomik ve toplumsal soruna da yol açmıştır. Bu çalışmada, kentsel dönüşüm sürecinde gecekondu mahallelerinde ortaya çıkan sorunların ve bunların toplumsal yansımalarının tespit edilmesi amaçlanmaktadır. Dolayısıyla çalışmada kentsel dönüşümün toplumsal boyutu ele alınarak, kentsel dönüşüm uygulanması planlanan gecekondu mahallelerinde yaşayan bireylerin karşılaştıkları sorunlar ve bunun yaşamlarına nasıl yansıdığı üzerinde durulmaktadır. Çalışma survey (tarama) araştırmasıdır. Buna göre çalışmada Sarıyer Derbent Mahallesi örneğinden hareketle, gecekondu bölgelerindeki halkın kentsel dönüşümle ilgili görüşleri ve bu süreçte ortaya çıkan sorunları ele alınmıştır. Alandan elde edilen veriler doğrultusunda kentsel dönüşüm sorunlarının toplumsal etkileri açıklanmaya çalışılmıştır. Çalışma sonucunda kentsel dönüşüm sürecinin Derbent Mahallesi halkını ekonomik ve sosyo-kültürel anlamda olumsuz etkilediği ve ortaya çıkan sorunların mahalle halkının kentsel dönüşüm projelerini destekleme davranışını farklılaştırdığı tespit edilmiştir.

Anahtar Kelimeler: Kentleşme, Göç, Gecekondu, Kentsel Dönüşüm, Toplumsal Sorunlar.

\section{Giriş}

Sanayileşme ve köyden kente göçle birlikte kentlerin yoğun göçten dolayı plansız bir şekilde büyümesi sağlıksız bir kentleşme sürecini ortaya çıkarmaktadır (Öngören ve Çolak, 2013: 23). Bu süreçte özellikle kentlerde yaşanan nüfus yığılmalarından dolayı yasal mekanizmaların yetersiz kalması, kaynakların sınırlı olması ve göç eden nüfusa konut sağlanamaması 'yasadışı konut üretimi'ne neden olmaktadır (Yılmaz, 2016: 33). Dolayısıyla göç eden nüfusun kendi gecekondularını yaparak kent merkezlerinin etrafında gecekondu bölgelerini oluşturması, bu bölgelerde sağlık, eğitim, toplumsal refah gibi konularda önemli sorunlarla karşılaşılmasına, kontrolsüz ve denetimsiz bir yapılaşmaya yol açmaktadır (Es ve Ateş, 2004: 209).

Kentlerin kontrolsüz ve denetimsiz büyümesinin neden olduğu altyap1 sorunları, sosyoekonomik sorunlar ve gecekondulaşmanın her geçen gün artarak devam etmesiyle birlikte bu durum, kentsel dönüşüm uygulamalarıyla kentlere müdahale edilmesi sonucunu doğurmaktadır. $\mathrm{Bu}$ uygulamalar, öncelikle konutlardaki düşük kaliteden kaynaklı sorunları ortadan kaldırmak, kentlerde sürdürülebilir çevre koşullarını yaratmak ve kentte yaşayan yoksul halkın yaşam standartlarını arttırmak gibi olumlu hedefler içerse de, olumsuz olarak ifade edilebilecek birçok soruna yol açmaktadır. Nitekim kentsel alanlarda yaşayan bireylerin sosyo-kültürel özellikleri göz önünde bulundurulmadan kente yapılan bu türden girişimlerin, öncelikle mekânsal alanda, sonrasında da buna bağlı olarak toplumsal alanda bir ayrışmaya ve dışlanmaya neden olan birçok sosyo-kültürel ve ekonomik problemlere yol açtı̆̆ gözlenmektedir.

Yaşam stadartlarının yükseltilmesi ve sağlıklı yaşam alanlarının oluşması için kentsel alanların yeniden yapılandırılarak kentsel bir dönüşüm sürecine gidilmesi kentlerin hem mekân bakımından hem de toplumsal yapı bakımından değişimini içermektedir. Bu nedenle kentsel dönüşüm uygulamalarının toplumsal olarak etkilerinin de ele alınması gerekmektedir (Güngör Ergan ve Kütük, 2007: 90). 
$\mathrm{Bu}$ çalışma, kentsel dönüşümün gecekondu alanlarında ortaya çıkardığı sorunları ve bu sorunların toplumdaki yansımalarını tespit etmeyi amaçlamaktadır. Buna göre çalışma, bir gecekondu mahallesi olan İstanbul ili Sarıyer İlçesinin Derbent Mahallesinde yaşayan bireylerle sınırlıdır. Survey (tarama) araştırması olan çalışmada, İstanbul'un Sarıyer ilçesi Derbent Mahallesi'nin kentsel dönüşüme tabi tutulmasıyla birlikte, mahalle halkının kentsel dönüşümle ilgili görüşleri, bu süreçle birlikte ortaya çıkan sorunlar ve bu sorunların toplumsal alandaki yansımaları alan verileri doğrultusunda ortaya konulmaya çalışılmaktadır.

\section{Kavramsal Bir Giriş: Kentleşme ve Gecekondu}

Kentleşme, zaman içerisinde meydana gelen bir değişmeyi, bir süreci anlatmaktadır. Sanayileşme ve ekonomik gelişmelere bağlı olarak kentlerin büyümesi ve sayılarının artması sonucunda toplum yapısındaki dönüşüm, bireylerin davranış kalıplarında ve toplumsal ilişkilerinde değişikliklere yol açmaktadır. Bu bağlamda kent sayısının ve kentlerde yaşayan nüfusun artmasıyla birlikte ortaya çıkan kentleşme sürecinde toplumların ekonomik, toplumsal ve siyasal yapısında önemli değişmeler meydana gelmektedir (Keleş, 1978: 5).

Kentleşmenin temel belirleyicisi olan nüfusun kırsal yerine kentsel bölgelerde yoğunlaşması sonucunda Türkiye'nin yaşadığı kentleşme sürecine bakıldığında, bu sürecin Avrupa ülkelerine göre çok daha kısa bir sürede ve hızlı yaşandığı söylenebilmektedir (Tekeli, 2008: 49). Buna göre Batı Avrupa ülkelerinde kentleşme, 18. yy.ın ortalarından itibaren yaşanan göç hareketleriyle birlikte sanayileşme ve sanayinin işgücü ihtiyacına paralel bir şekilde düzenli bir biçimde gerçekleşirken bu durum Türkiye açısından ele alındığında farklılaşmaktadır (Koyuncu, 2012: 379). Nitekim Türkiye'de özellikle 1950'li yıllarda hız kazanan göçler doğrultusunda ortaya çıkan kentleşme olgusunun arkasında sanayileşme ile birlikte tarımda makineleşme, işsizlik, kan davası gibi kırın iticiliğinden kaynaklanan sebepler yer almaktadır (Sağlam, 2006: 37). Bu yüzden Türkiye kentleşmesinin özelliği olarak göçler tek yönlü olarak kırdan kente göç şeklinde erkek iş gücü ile başlamakta, diğer aile fertlerinin daha sonra kente getirilmesiyle devam etmektedir. (Es ve Ateş, 2004: 217-218). Bu nedenlerden ötürü kentlere yönelen göçün hızlanması ve kentleşmenin sanayileşme ile orantılı ilerlememesi, Türkiye özelinde gerçekleşen kentleşme deneyiminin sağlıksız ve düzensiz bir şekilde yaşanmasına neden olmaktadır. Dolayısıyla bu durum plansız ve çarpık kentlerin ortaya çıkmasına, bazı kentlerin aşırı büyümesine, konut ve altyapı hizmetlerinin yetersiz kalmasına ve kentlerin etrafında gecekondu bölgelerinin oluşmasına yol açmaktadır (Erman, 1998: 47, Özer, 2004: 67; Es ve Ateş, 2004: 208-209).

775 say1lı gecekondu yasasına göre "imar ve yapı işlerini düzenleyen mevzuata ve genel hükümlere bağll kalınmaksızın, kendisine ait olmayan arazi veya arsalar üzerinde, sahibinin rızası alınmadan yapılan izinsiz yapılar" gecekondu olarak tanımlanmaktadır (12362 Sayılı Resmi Gazete, 1966). Tanımdan da anlaşılacağı üzere her ne kadar 'yasadışı konut'olarak tanımlansada gecekondular, bir yerleşim biçimini ve yaşam tarzını ifade etmektedir (Kıray, 1998: 27; Türkdoğan, 2006: 49). Kentleşme sürecinde ortaya çıkan, göçle birlikte gelen insanların kedisini ne köylü ne de kentli hissettiği, kente uyumu kolaylaştıran ve toplumsal bütünleşme sağlayan gecekondular bir 'tampon kurum' işlevi görmektedir (Kıray, 1964: 7). Bu konuda, gecekonduda yaşayan bireyler için kullanılan "yeni kentliler" kavramı karşımıza çıkmaktadır. "Yeni kentliler" köy ve kent yaşamı arasında kalan, ancak hem kentten etkilenen hem de kenti etkileyen kültürel bir alış-veriş süreciyle karşılaşmaktadırlar (Türkdoğan, 2006: 53). Dolayısıyla gecekondular, kente göç eden nüfusun uyum sürecinde köy yaşamından tamamen kopmadan buna karşılık kentteki yaşamından da soyutlanmadan kente alışmasına yardımcı olmakta ve içinde yaşayan bireyi, yabancı kaldığ 1 kent yaşamından koruyarak ona yaşama firsatı tanımaktadır (Alver, 2010: 14).

Türkiye'de gecekondulaşma, yaşanan göç ve işsizlik sonucunda daha gelişmiş ve daha büyük kentlerin olduğu alanlarda yoğunlaşmıştır (Güngör Ergan ve Kütük, 2007: 84). Örneğin İstanbul'daki gecekondular, sanayi kuruluşlarının yoğun olarak bulunduğu bölgelerde ya da yerel yönetimin sınırlarına yakın yerlerdeki arsalar üzerinde kurulmuştur. (Keleş, 1978: 187). Türkiye'de 
gecekondular ile ilgili eleştiriler mevcut olmakla birlikte özellikle konut edindirme yöntemlerinin yeterli olmadığı durumlarda gecekondunun olumlu özellikler taşıması ve başarılı bir yöntem sayılabilmesi söz konusu olmaktadır. Özellikle toplumsal konut üretiminde ortaya çıkan açığın kapatılmasında etkili olması, bu bölgelerde yerleşmiş olan insanlar arasında dayanışma duygularının gelişmesini sağlaması, aylak işgücüne çalışma alanı açması ve emeğin yeniden üretimini sağladığından sadece emek için değil sermaye için de en uygun çözüm yolu olması gecekonduların olumlu nitelikleri olarak gösterilebilmektedir. Bunun yanında olumsuz nitelikleri arasında ise; kuruldukları arsaların sağlıklı bir yaşam için elverişli olmaması, altyapı ve kentsel hizmetlerin yetersizliği, kötü beslenme ve yüksek nüfus yoğunluğundan dolayı bulaşıcı hastalıkların görülebilmesi, yapım sürecinin ticarileşmesi gibi etkenler yer almaktadır (Keleş, 1996: 381-385).

\section{Kentsel Dönüşüm ve Bu Süreçte Ortaya Çıkan Toplumsal Sorunlar}

Kentler tarihsel süreç içerisinde, doğalarının gereği değişip dönüşmektedir. Ancak çalışma konusu kapsamında ele alındığında kentsel dönüşüm kavramıyla anlatılmak istenilen, kentlerin doğaları gereği yaşadıkları dönüşüm değil, dışardan müdahale edilmesiyle ortaya çıan dönüşümdür (Yıldız ve Zümrüt, 2012: 399). Buna göre kentsel dönüşümle birlikte imar planına uymayan ruhsatsız yapıların yıkılarak plana uygun bir şekilde yapılması ve istenilen toplu yerleşim alanlarının oluşturulması amaçlanmaktadır (www.tdk.gov.tr, 2020).

Ülkeden ülkeye ve tarihsel süreç içinde farkl1lık göstermekle birlikte kentsel dönüşümün düşük yaşam koşullarının iyileştirilmesi, altyapı eksikliklerinin giderilmesi, toplumsal dışlanmanın azaltılması, çok paydaşlı ve katılımlı planlama aracılı̆̆ıyla kentsel politikanın biçimlendirilmesi, çöküntüye uğramış, eskimiş kent alanlarının yenilenmesi, hali hazırda bulunan ve yeni yapılacak olan yapılarla ilgili kararlar alınması gibi pek çok amacı bulunmaktadır (Yıldız ve Zümrüt, 2012: 399; Özden, 2008: 45-46). Bu amaçlarla dönüşüm sürecindeki kentlerin konut alanları, kent merkezleri, sanayi alanları, afet riski taşıyan alanlar, liman ve dok alanları gibi farklı işlev alanlarını barındırıyor olmasından yola çıkılarak her bir alan için farklı şekilde müdahaleler geliştirilmektedir. Nitekim bu alanlardan birinin kentsel dönüşüm alanı olarak ilan edilmesinden sonra gerçekleştirilmesi planlanan uygulamanın türüne karar vermek gerekmektedir. Bu süreçte uygulanması planlanan müdahale tarzı belirlenirken, hedeflenen iyileştirmenin niteliği, yapıların konumu ve nitelikleri göz önünde bulundurularak, alandaki sorunun ne olduğunun, yapılmas1 planlanan müdahalenin ne kadar gerekli olup olmadığının tespiti önem taşımaktadır (Öngören ve Çolak, 2013: 252). Bu yüzden seçilecek olan uygulama yönteminin kentin vizyonuna ve ortaya koyduğu hedeflere ulaşmayı sağlayacak bir yöntem olması gerekmektedir (Özden, 2008: 233). Kentsel dönüşüm alanı ilan edilen bölgede nasıl bir yöntem kullanılacağının belirlenmesinin yanında bu alanda bulunan aktörlerin ve rollerinin belirlenerek sınırlarının çizilmesi de kentsel alanların gerçekten bir bütün olarak yenilenebilmesi anlamında önem taşımaktadır (Özden, 2008: $380)$.

Kentsel dönüşümün Türkiye uygulamalarına bakıldığında, özellikle kullanıcı ihtiyaçlarına uygun olup olmadığı ve kentlerin kimliği ile olan tutarlı olup olmaması bakımından tartışma konusu olduğu görülmektedir. Bu durumun ortaya çıkmasında, kentsel dönüşümün sadece fiziki mekân düzenlemesi olarak algılanması, mimari ve kentsel kimliğin göz ardı edilerek üretilmesi, yeni mekânların kentin ruhuna ve mekânına yabancılaşması etkili olmaktadır (Görgülü, 2009: 771). Nitekim ekonomik, toplumsal ve çevresel koşullar göz önünde bulundurularak kentsel alanları yenileme gerekçesiyle yeni yaşam alanlarının oluşturulması, insanların yaşam standardının yükseltilmesi, yoksulluğun azaltılması gibi olumlu etkileri içinde barındıran kentsel dönüşüm sürecinde yapılan projeler kapsamında gecekonduların yerini apartmanlar alırken mahalle halkı yaşam alanlarını terk etmek zorunda kalabilmektedir. Bununla birlikte kentin doğal, kültürel ve tarihi dokularının zarar görmesi, kent kimliğinin değişmesi, yeni yoksul mahallelerin ve yeni dışlanmışlık duygularının oluşumu, bunun sonucunda çatışma ve suç oranlarının artması gibi 
sorunlar ortaya çıkabilmektedir (Beyazıt, Gül ve Güneş, 2013: 156-159; Özden, 2010: 282-283; Ertan, 2014: 211). Özellikle gecekondu bölgelerinin kent merkezlerinde kalmasına yönelik çıkarılan imar yasalarının da etkisiyle bir yandan gecekonduların apartmana dönüşümü diğer yandan bu bölgelerdeki kentsel toprak rantının yükselmesi, gecekondu alanlarının ticari rant alanlarına dönüşmesine yol açabilmektedir (Aydın, 2007: 37). Bu doğrultuda kentsel dönüşümün tartışma konusu olmasına neden olan, dönüşüm sürecinde veya sonrasında birçok sorunla karş1laş1labilmek mümkündür.

Özetle göçle birlikte kentleşme sorunlarının ortaya çıkması uzun dönemde kentsel yapının değişmesine ve dönüşmesine neden olmakta ve bu süreçte uygulanması planlanan kentsel dönüşüm projelerinin, ekonomik, toplumsal ve mekânsal alanda olumlu ve olumsuz etkileri görülmektedir.

\section{Araştırma Sahasının Özellikleri}

İstanbul'un Sarıyer ilçesi sınırlarında bulunan Derbent Mahallesi hala devam etmekte olan ve oldukça uzun bir geçmişe dayanan, kentsel dönüşüm süreçlerine en yakından şahitlik eden mahallelerden biridir. Mahallenin kuruluş süreci 1950'lere dayanmakla birlikte gecekondulaşmanın hızlanması 1970'lerden sonra gerçekleşmiştir. 1980'li yıllarda arka arkaya çıkan af yasalarının da etkisiyle gecekondular çok katlı apartmanlara dönüşmeye başlamıştır. Mahallenin bir iş merkezine, hastaneye, metro durağına olan yakınlığı ve Boğaza ulaşım noktasında yer alması gibi özellikler bir araya geldiğinde, İstanbul gibi bir metropol içerisinde mahalle önemli bir konumda yer almaktadır. Dolayisıyla bütün bu sebeplerin de etkisiyle Derbent Mahallesi kentsel dönüşüm süreçlerinin odağında bulunmaktadır.

Mahallenin dönüşüm açısından nasıl bir süreçten geçtiği şu şekilde özetlenebilir ${ }^{1}$; Atatürk Oto Sanatkârları Yapı Kooperatifi 1987 yılında açtığı izale-i şüyu davası sonucunda mahalledeki arazilerin bir kısmını almış ve süreç bu araziye birçok konutun yapılmasıyla devam etmiştir. 2005 y1lında ortaya çıkan kentsel dönüşüm söylentileri nedeniyle bir mahalle derneği kurulmuş, 2006 yılında ise bu derneğin yıkımı gerçekleşmiştir. 2006 yılından itibaren bir inşaat firması mahalle ile ilgili kentsel dönüşüm sürecine dâhil olmuş, ardından 2012 yılında mahallede yaşayan 40 aile ile anlaşarak evlerini boşaltmaları sağlanmış ve bu kişiler Kağıthane'de bulunan konutlara yerleştirilmişlerdir. 2012 yılında avan proje hazırlanmış ve kentsel dönüşüm süreci fiili olarak başlatılmıştır. 2013 yılında ise mahalle riskli alan ilan edilmiş ve süreç mahalle halkının açtığı iptal davasının kazanılmasıyla devam etmiştir. Mahalle halkının kentsel dönüşüm pratiği mahalle kooperatifinin de kurulmasıyla daha kurumsal ve örgütlü şekilde devam etmiş, gerek riskli alan kararının iptali gerekse arazilerin mahalleliye devri anlamında çabalar devam etmiştir. Nitekim süreç boyunca kentsel dönüşüm konusunda oluşan toplumsal muhalefet hala devam etmektedir. Planlanan projelerin mahalle halkının asıl amacı olan yerinde dönüşüm talebini karşılamaması, yine planlanan projelerin mahallenin sosyo-ekonomik yapısını ve mahallede yaşayan bireylerin yaşam pratiklerini göz önünde bulundurarak hazırlanmaması, mahalle için planlanan konutların sosyal dokuyu, dayanışma ilişkilerini, mahalle kültürü ve komşuluk ilişkilerini olumsuz etkileyeceği ve yaşam şekillerini değiştireceği düşüncesi kentsel dönüşüme karş1 oluşan toplumsal muhalefetin temel sebepleri arasinda yer almaktadır.

Kentsel dönüşüm süreçlerinin yarattığ yansımalarını sosyolojik açıdan analiz etmeyi amaçlayan bu çalışmada, yukarıda özetlemeye çalıştığımız süreçleri çok uzun süredir ve her yönüyle deneyimleyen bir mahalle olması bakımından Derbent Mahallesi ele alınmıştır. Araştırmanın kentsel dönüşüm sürecinin belirsizliğinden kaynaklanan sorunların ve gelecek ile ilgili oluşturduğu endişelerin analiz edilmesini de içermesi, dönüşüm süreçlerinin ve mücadelelerin hala devam ettiği bir mahalle olan Derbent mahallesinin konu olarak seçilmesinde etkili olmuştur.

\footnotetext{
${ }^{1}$ Araştırma sahası ile ilgili bilgiler, Mahalle Kooperatifi arşivinden ve örneklem grubu ile yapılan görüşmelerden elde edilmiştir.
}

Turkish Studies, 15(5) 


\section{Araştırmanın Yöntemi Ve Teknikleri}

Bilimsel bir araştırma sürecinde; öncelikle araştırma konusunun tespit edilmesi, konuyla ilişkin hipotezlerin oluşturulması, araştırma konusuna uygun yöntem ve tekniklerin belirlenmesi, verilerin toplanarak değerlendirilmesi ve elde edilen verilerden hareketle araştırmanın sonuçlanması gerekmektedir (Türkdoğan, 1989: 154). Dolayısıyla araştırmada bahsi geçen süreçler dikkate alınarak araştırma modeline uygun hareket edilmeye çalışılmıştır.

$\mathrm{Bu}$ çalışmada, kentsel dönüşüm sürecinde gecekondu mahallelerinde ortaya çıkan sorunların ve bunların toplumsal yansımalarının tespit edilmesi amaçlanmaktadır. Buna göre 'kentsel dönüşüm sürecinin Derbent Mahallesi halkını ekonomik ve sosyo-kültürel anlamda olumsuz etkilemekle birlikte bu süreçte yaşanan toplumsal sorunlar, mahalle halkının kentsel dönüşümü destekleme davranışını farklılaştırdığı' bu makalenin temel hipotezini oluşturmaktadır.

Çalışma bir survey (tarama) araştırmasıdır. Survey araştırmasında, çalışmanın evrenini İstanbul / Sarıyer ilçesinin Derbent Mahallesi'nde yaşayan bireyler oluşturmaktadır. Buna göre Derbent Mahallesi'nde yaşayan toplam 6.186 kişi çalışmanın evrenini oluşturmaktadır. Araştırma örneklemi, basit tesadüfi örnekleme tekniği ile hesaplanarak örneklem büyüklüğü 365 olarak belirlenmiştir. Araştırmada evreni temsil eden örneklem grubuna uygulanması için kentsel dönüşüm sürecindeki gecekondu bölgelerinde ortaya çıkan toplumsal sorunları tespit etmeye yönelik olarak bir anket formu hazırlanmıştır. Anketlerin tamamı araştırmacının bizzat kendisi tarafından uygulanmış, böylelikle örneklem grubuna sorulan soruların anlaşılmaması gibi durumlar engellenmeye çalışılmıştır. Böylelikle sahadan elde edilen gözlemlerle birlikte araştırmanın bulgularının daha kapsamlı şekilde yorumlanması amaçlanmıştır. Araştırmanın bulguları, seçilen örneklem ve yapılan zaman dilimi ile sınırlandırılmıştır. Elde edilen veriler, bilgisayar ortamında, sosyal bilim araştırmaları için uygun olan istatistik programı kullanılarak analiz edilmiştir.

\section{Verilerin Değerlendirilmesi}

\section{Demografik Özellikler}

Çalışma için hazırlanan anketin uygulandığı örneklem grubu içerisinde kadın ve erkek oranı neredeyse eşittir. Buna göre örneklem grubunun yaklaşık \%49'u (178 kişi) "kadın”, \%51'i ise (182 kişi) “erkek" olmak üzere toplam 360 mahalle sakini ile görüşülmüştür.

Örneklem grubunun yaklaşı \%66'sını 26 yaş ve 55 yaş grubu arasında bulunan bireyler oluşturmaktadır. Bunun dışında görüşülenlerin yaklaşık \%10'u " 25 yaş ve altında", \%24'i ise "56 yaş ve üzeri" örneklem grubu içerisinde temsil edilmektedir.

Medeni durum bakımından ele alındığında görüşülenlerin yaklaşık \%79'unun evli olduğu görülmektedir. Evli olanların yaklaşık \%29'unun ' 2 ' çocuğa \%22'sinin ise ' 3 ' çocuğa sahip oldukları tespit edilmiştir.

Doğum yeri bakımından örneklem grubunun yaklaşı \%51'i ilde, \%27'si ise ilçede doğmuştur. Buna göre görüşülenlerin çoğunluğunun il doğumlu olduğu göz önüne alındığında bu durum gecekondu mahallesinde yaşayan mahalle sakinlerinin kente uyum sağlama ve kentlileşme süreçleri bakımından onların yaşam koşullarını, yaşamı algılama, değerlendirme biçimlerini ve davranışlarını etkileyebilmektedir.

\section{Sosyo-Kültürel Özellikler}

Araştırmaya katılanların eğitim düzeyine bakıldığında, mahalle sakinlerinin eğitim seviyesinin yüksek olmadığ 1 söylenebilir. Buna göre mahalle sakinlerinin toplam \%87'si "okuryazar olmayan", "okur-yazar olan fakat hiç eğitim almayan", "ilkokul", "ortaokul" ve "lise ve dengi" bir okuldan mezundur. Cinsiyet bakımından ele alındığında ise örneklem grubunda yer alan erkeklerin eğitim seviyesi kadınların eğitim seviyesinden daha yüksektir. 
Mesleki dağılımları bakımından ise örneklem grubunun çoğunluğu "ev kadınları"ndan $(\% 31,6)$, "serbest meslek sahipleri"nden $(\% 19,8)$ ve "işçiler"den $(\% 19,6)$ oluşmaktadır. Görüşülenlerin yarısından fazlasının "2.500 TL ve altında" aylık gelir durumuna sahip olduğu tespit edilmiştir. Hane halkı özelliklerine bakıldığında ise görüşülenlerin dörtte üçünün hanesinde "2-4 kişinin” yaşadığı anlaşılmıştır. Buna göre örneklem grubunun ortalama '2' çocuğa sahip olduğu göz önüne alındığında Derbent Mahallesinde yaşayan bireylerin çekirdek aile yapısına sahip olduğunu göstermektedir. Hanede çalışan kişi sayısı bakımından ele alındığında ise örneklem grubunun yaklaşık \%37'sinin hanesinde bir kişi, \%30'unun hanesinde iki kişi çalışmakta olup hane içerisinde hiç çalışmayanların oranı ise yaklaşık \%17 olarak yer almaktadır.

Görüşülenlerin mahalledeki toplumsal yaşam ile dayanışma ilişkilerine yönelik görüşleri ele alındığında, çoğunluğunun (\%86) bu mahallede yaşamaktan "çok memnun" ve "memnun" oldukları belirtilmektedir. Örneklem grubuna göre Derbent mahallesini yaşanabilir kılan unsurlar arasında öncelikle "komşuluk ilişkilerinin sağlam olması" (\%35,7), "yardımlaşma-dayanışmanın güçlü olması" (24,5) ve "doğup büyüdü̈̆̈̈ yer olması" $(\% 13,4)$ gibi etkenlerin yer aldı̆̆ görülmektedir. Ayrıca görüşülenlerin mahallede hem hemşehrilerinin hem de akrabalarının bulunduğu (\%76), mahalle halkının komşuluk ilişkilerinin "çok iyi" (\%60,3) olduğu ve komşularıyla "her gün" $(\% 53,9)$ görüştükleri ve ihtiyaç halinde ilk komşularından yardım istedikleri $(\% 60,8)$ ve en çok "manevi konular" da $(\% 26,4)$ yardımlaştıkları saptanmıştır. Buna göre elde edilen verilerden hareketle Derbent Mahallesi'nde yaşayan bireylerin komşuluk ilişkilerinin iyi olduğu ve mahalledeki yardımlaşma ve dayanışma ağlarının güçlü olduğu söylenebilir. $\mathrm{Bu}$ bağlamda çalışma literatürle ilişkilendirildiğinde mahalle içerisindeki komşuluk ilişkilerinde benzerlik görülmektedir. Örneğin, İstanbul Çekmeköy'de yaşayan bireylerin yeni konutlaşma eğilimlerini tespit etmek amacıyla yapılan bir çalışmada (Firidin Özgür, 2006: 88), Çekmeköy'deki sitelerin etrafındaki kesimin temsili olarak seçilen Hamidiye Mahallesi'nde yaşayanların komşuluk ilişkilerinin (\%35) çok iyi olduğu, mahalle sakinlerinin mahalle içerisinde samimi bir toplumsal ortam oluşturmaya çalıştıkları tespit edilmiştir. Başka bir çalışmada da (Yücel ve Aksümer, 2011: 126) İstanbul'unbir gecekondu bölgesi olan Sarıyer Kazım Karabekir Mahallesi'nde yaşayan görüşülenlerin komşuluk ilişkilerinin (\%79) iyi olduğu, mahallede yakınlarının bulunduğu $(\% 70)$ ve 30 yıldan daha fazla bir sürede $(\% 62)$ aynı mahallede yaşadıkları ifade edilmiştir. Benzer şekilde Ankara ilinin Altındağ ilçesindeki bir gecekondu mahallesi olan Hacılar Mahallesinde yapılan bir çalışmada ise mahalle halkının komşuluk ilişkilerinin iyi olduğu ve çoğunlukla akrabalarının ve hemşehrilerinin aynı mahallede oturdukları görülmüştür (Güngör Ergan ve Kütük, 2007: 99). Dolayısıyla gecekondu bölgelerinde yaşayan mahalle halkı arasında komşuluk ilişilerinin iyi olması, mahalle içerisinde hemşehrilerinin ve akrabalarının yoğunlukta olması vb. etkenler mahalle sakinlerinin oturdukları yere olan bağlılı̆̆ını güçlendirdiği söylenebilir.

\section{Göç ve Konut Bilgisi}

Örneklem grubunun yarıdan fazlası İstanbul'a (\% 60) göç etmiştir. Göç etme sebebi olarak "ekonomik sorunlar"ın (\%71,2) ilk sırada yer aldığ görülmektedir. Bunu "işsizlik" $(\% 12,6)$, "evlilik" $(\% 8,4)$, "eğitim" $(\% 2,8)$ ve "terör" $(\% 1,4)$ sorunları takip etmektedir. Kentlerde gecekondu alanlarının işgücünün önemli bir kısmını barındıran yerler olduğu göz önüne alındığında, buralara yapılan göçün sebepleri arasında ekonomik sebeplerin ilk sırada olması beklenen bir durumdur.

Çalışmaya katılan görüşülenlerin yaklaşık \%70'inin 26 yıl ve 50 yıl arasında bu mahallede yaşadıkları görülmüştür. Dolayısıyla bu durum mahalle halkının 1980'li yıllardan sonra şehre göç ettiklerini ve bu alanlarda gecekondulaşmanın ortaya çıktığını göstermektedir. Bunun nedenleri arasında yaşanan yoğun göç sonucunda 1980'li yıllardan itibaren ruhsatsız yapılaşma sorununa çözüm olarak birbiriyle ilişkili çıkarılan af yasalarını göstermek mümküdür. $\mathrm{Bu}$ yasalarla gecekondu alanlarının mülkiyet sorunlarının çözülmesi ve gecekondu stokunun piyasa koşulları da 
göz önünde bulundurularak apartman türü konutlara dönüştürülmesi amaçlanmaktadır (Ataöv ve Osmay, 2007: 66).

Mahallede yer alan konut türü bakımından görüşülenlerin yaklaşık \%51'inin tek katlı gecekondularda, yaklaşık \%24'ünün ise müstakil bir evde oturdukları tespit edilmiştir. Hatta bazı gecekondu sahiplerinin gecekonduda otursa bile yaşadıkları konutu müstakil ev olarak tanımlamaktadır. Buna göre örneklem grubunun konut tanımlamasında oturdukları gecekonduları 'yasadış1lı veya kurallara aykırı olma hali'nden çok konutun kat sayısını baz alarak bir tanımlama yaptıkları görülmektedir. Ayrıca konutların büyüklügü̈ ailede yaşayan kişi sayısı ve aile üyelerinin ihtiyaçlarına göre değișiklik göstermektedir. Mahallede yapılan gözlemler sonucu hane halk1 sayısının artması, özellikle çocuklarının evlenmesiyle birlikte odaların genişletildiği, var olan gecekondunun üzerine kat çıkıldığı veya aynı bahçe içerisine bir başka gecekondu yapıldığ 1 , bu sebeple mahallenin kurulduğu zamana göre gecekonduların şuan çok farklı görünümlerde olduğu söylenebilir.

Konutların mülkiyet durumu bakımından ele alındığında örneklem grubunun yaklaşık \%91'inin ev sahibi oldukları ve yaklaşık \%78'inin oturdukları evleri kendilerinin yaptıkları, buna karşılık \% 8'inin kiracı oldukları tespit edilmiştir. Oturulan konuta ilişkin ev sahiplerinin sahip oldukları belgeler arasında ise yaklaşık \%54'ünün tapu tahsis belgesine sahip oldukları ve oturdukları konutun bulunduğu araziyi ise mahalle halkının büyük çoğunluğu tarafından mahalleye gelindiğinde belirli bir ücret karşılığında satın aldıkları görülmüştür. Buna göre Derbent Mahallesi'nde yaşayanların tamamına yakının ev sahibi oldukları ve yaklaşık dörtte üçünün de kendi gecekondularını kendilerinin yaptıkları görülmüștür. Mahalle halkının en büyük sorunları arasında ilk sirada "tapu sorunu" $(68,1)$ gelmekte ve sonrasinda "ylkım tehlikesi" $(\% 8,6)$ ve "altyapı sorunları" $(\% 4,2)$ yer almaktadır. Ancak bütün bu sorunlara karşıllık mahalleden taşınmak zorunda kaldıklarında mahalle halkının yaklaşık \% 28'i Derbent Mahallesi'ne benzer bir yere gitmek istediklerini belirtmektedirler. Taşınmak zorunda kalma durumunda yine kendi mahallelerine benzer bir yerde yaşamak istemeleri, mahallede yaşama sürelerinin 26-50 yıl arasında olması gibi faktörler değerlendirildiğinde, Derbent mahallesi halkının, yaşadıkları yere aidiyet duygularının oldukça fazla olduğu, mahalleyi sahiplendikleri söylenebilir. Bu sebeple kentsel dönüşüm planlarına karşı ortaya çıkan toplumsal muhalefet genellikle mahalleden ayrılma fikrine karşı oluşmaktadır.

\section{Sorunlar}

Gecekondu Bölgelerinde Kentsel Dönüşüm Sürecinde Ortaya Çıkan Toplumsal

\section{Mahalle Halkına Göre Kentsel Dönüşümün Anlamı}

Derbent Mahallesi halkının kentsel dönüşümün anlamının ne olduğuna yönelik görüşleri sorulduğunda araştırmaya katılanların yaklaşık \%34'ü "rant sağlamak", \%18'i "varlıklı kesime yeni yaşam alanlart sunmak", \%17'si "yoksul kesime yeni yaşam alanlart sunmak" ve \%15'i ise "depreme dayanıksı binaların kiyılarak yerine yenilerinin yapılmasını sağlamak" cevabını vermişlerdir. Verilerden ve gözlemlerden hareketle mahalle halkının yaşadıkları kentsel dönüşüm sürecindeki tecrübelerini de göz önünde bulundurarak kentsel dönüşüm kavramına daha çok olumsuz anlamlar yükleme eğiliminde oldukları söylenebilir.

Görüşülenlere kentsel dönüşüm sürecinin olumlu ve olumsuz yanları sorulduğunda ise birden çok etkenle karşılaşılmaktadır. Buna göre örneklem grubunun yaklaşık \%27'si "plansız ve çarpık bir kentleşmenin sona ermesi", \%25'i "konutların yenilenmesi ve sağlamlaştırılması" ve \%8'inin ise "modern ve çağa uygun konutların yapılması" için kentsel dönüşümün gerekliliği üzerinde durmaktadırlar. Buna karş1l1k görüşülenlerin yaklaşık \%17'si "mahalle kültürünün ve komşuluk ilişkilerinin yok olması", \%13'ü "mahalleden ayrılmak zorunda kalınması" ve \%13'ü ise "rant paylaşımında eşitsizliklerin ortaya çıkması" gibi etkenlerden dolayı kentsel dönüşüme olumlu bakmamaktadırlar. Özellikle görüşülenlerde dönüşüm süreciyle birlikte yeni yaşam şartlarına sahip 
olacaklarını buna karşılık eski sosyal ilişkilerini sürdüremeyecekleri düşüncesi yer almaktadır. Yapılan bir çalışmada da (Güneş, 2014: 67, 69, 71) kentsel dönüşümün olumlu yanları olarak evlerin yenilenerek depreme dayanıklı hale getirilmesi ve yenilenen evlerin değerinin ve konforunun artması gibi etkenlerin kentsel dönüşümün olumlu yanları olarak ifade edilmektedir. Olumsuz yanları olarak ise kentsel dönüşümle birlikte mülk sahiplerinin haklarından çok rant düşüncesinin ön plana çıkması, mahallelerinden, arkadaşlarından ve komşularından ayrılmak zorunda kalmaları gibi etkenler dile getirilmektedir. Buna göre gecekondulaşmanın, kentteki yaşama uyum sağlama bakımından kendileri gibi göç etmiş bireylerle bir arada olmak, sosyokültürel ve ekonomik açıdan benzer özelliklere sahip olmak bakımından tampon bir mekanizma işlevi gördügü ifade edilebilir (Mutlu, 2007: 20).

\section{Kentsel Dönüşüme Destek Davranışı}

Kentsel dönüşüm, mekânsal, ekonomik ve sosyal anlamda ortaya çıkan sorunların kentin problemlerinin çözümü için gerçekleştirilen müdahaleleri içeren, kentsel alanlarda yeniden yaşanabilir kılmayı hedefleyen bir süreç olarak ifade edilebilir (Girit Macdaniel, 2010: 43).

Kentsel dönüşüme destek davranışı bakımından görüşülenlerin yaklaşık \%51'i Derbent Mahallesi'nde kentsel dönüşümün gerekli olduğunu düşünmektedir. Örneklem grubunun yaklaşık \%45'i uygulanması planlanan kentsel dönüşüm hakkında ortak bir noktada buluştuklarını, yaklaşık \%38'i ise komşularıyla aralarında anlaşmazlık yarattığını ifade etmektedir. Güneş'in yaptığı bir çalışmada da (2014: 64-65) görüşülenlerin kentsel dönüşüme destek verdiklerini ve kentsel dönüşüme yenilenme olarak baktıkları belirtilmektedir. Buna karşılık kentsel dönüşüme destek vermeyenlerin ise, bu dönüşüm sürecinin asıl amacının rant sağlamak olduğu ve dönüşümle birlikte mülk sahiplerinin borçlandırılarak mağdur edilecekleri dile getirilmektedir.

Ayrıca kentsel dönüşümün gerekliliği ile oturulan konutun büyüklüğü arasındaki ilişki [x2(10)=17.852, p<0,05] ele alındğında, kentsel dönüşümün gerekli olduğunu söyleyenlerin \%60'1 $50-100 \mathrm{~m} 2$ arası konutlarda oturmakta iken, kentsel dönüşümün gerekli olmadığını söyleyenlerin ise $\% 51$ 'i 100-150m2 arası konutlarda oturmaktadır. Mahalle için tasarlanan son proje kapsamında mahalle halkına verilmesi öngörülen konutların, Derbent Mahallesi halkının aile yapısı ve çocuk sayısı ile ilgili olarak düşünüldüğünde oldukça küçük olması, özellikle şuan yeterli büyüklüğe sahip konutlarda oturanların kentsel dönüşümü gerekli görmemesi üzerinde etkili olan bir durumdur. Bunun yanında yaşanılan mahalleden memnun olma ile kentsel dönüşümü gerekli görme arasında [x2(8)=23.402, p $<0,05]$ anlamlı bir ilişki bulunmaktadır. Buna göre mahallede yaşamaktan "memnun olmayanlar"'n yaklaşık \%83'ü "klsmen memnun olanlar"1n ise \%72'si kentsel dönüşümümn gerekli olduğunu ifade etmektedir. Buna karşlık mahallede yaşamaktan "çok memnun olanlar"'n yaklaşık \%50'si ve “memnun olanlar"1n \%37'si kentsel dönüşümün gerekli olmadığını belirtmektedir. Buna göre yaşanılan mahalleden memnun olma oranı artıkça kentsel dönüşümün gerekli olmadığı ya da yaşanılan mahalleden memnun olma düzeyi düştükçe kentsel dönüşümün gerekli olduğu konusunda fikirler ileri sürülmektedir.

Örneklem grubunun tamamı yaşadıkları mahalle ile ilgili kentsel bir dönüşüm planından haberdar olduklarını ve bu dönüşüm sürecini ilk olarak "yakınları"ndan $(\% 63,6)$, duyduklarını belirtmektedir. Ayrıca görüşülenlerin yaklaşık \%78'i öngörülen dönüşüm projesi ile ilişkili olarak yetkili birimler tarafindan bilgilendirilmediklerini ve resmi kurumların projeyle ilgili bilgilendirme çalışmalarını yeterli bulmadıklarını $(\% 91,4)$ ifade etmektedir. Yapılan bir çalışmada da kentsel dönüşüm projesi kapsamındaki bir gecekondu mahallesinde oturan görüşülenlerin mahallelerinde yapılacak dönüşümle ilgili yetkili birimler tarafından bilgilendirilmediklerini, projeyle ilgili bilgiyi öncelikli olarak toplumsal çevreden edindiklerini belirtmektedirler (Güngör Ergan ve Kütük, 2007: 99). Ayrıca çalışma kapsamında araştırmaya katılanların \%83'ü ise proje hakkında bilgi sahibi olmadıkları için öngörülen projeyi onaylamadıklarını ifade etmişlerdir. Buna göre proje hakkında bilgi sahibi olma ile projeyi onaylama arasında $[x 2(2)=14.981, p<0,05]$ anlamlı bir ilişki olduğu görülmüştür. 
Mahalle halkının kentsel dönüşüme destek davranışı ele alıdığnda bunun demografik özelliklere, konutun mülkiyet durumuna göre farklılaştı̆̆ 1 tespit edilmiştir. Buna göre cinsiyet ile kentsel dönüşümü onaylama davranışı arasındaki ilişki ele alındığında kentsel dönüşümü onaylayanların \%30'unun "kadın", \%70'inin ise "erkek" olduğu görülmüştür. Ayrıca ev sahiplerinin yaklaşı \% $\% 1$ 'ü kiracıların ise \%59'unun geçmişte olan kentsel dönüşüm projesini onaylamadıklarını ifade etmişlerdir. Buna göre ev sahibi olan görüşülenlerin kentsel dönüşüm sürecinde daha fazla hak kaybına uğrayacaklarını düşündükleri için bu projeyi onaylamadıkları söylenebilir. Nitekim görüşülenlerin yaklaşı $\% 35^{\prime} \mathrm{i}$ proje konusunda mahalle halkına sorulmamasından, \%32'si ise proje kapsamında yapılan konutlardan mahalle halkına daha küçük konutların ayrılmasından dolayı kentsel dönüşüm projesini onaylamadıklarını belirtmişlerdir. Sağl1klı bir kentsel dönüşümün gerçekleşmesi için gerekli olan katılım faktörünün kentsel dönüşümün tüm aktörleri için eşit şekilde gerçekleşmesi gerekmektedir. Bu konuda sürece ortak olan özellikle resmi kurumların halkı bilgilendirme ve sürece dahil etme konusunda yeterli olmadığı söylenebilir. Nitekim resmi kurumlar tarafından bilgilendirilmeyerek, talepleri göz önünde bulundurulmayan mahalle halkı kentsel dönüşümü onaylamamaktadır.

\section{Kentsel Dönüşüm Sürecinin Toplumsal Yansıması}

Derbent Mahallesi için öngörülen kentsel dönüşüm doğrultusunda planlanmış olan projenin aktörleri tarafından uygulamaya konulmaması, mahalle halkının kentsel dönüşümle ilgili belirsiz bir süreç yaşamasına neden olmuştur. Nitekim araştırma sonuçlarına göre görüşülenlerin $\quad \% 90$ '1 içinde bulundukları sürecin belirsizliğinden dolayı gelecek endişesi yaşadıklarını ve bu yüzden \%87'si konutlarıyla ilgili uzun vadeli plan yapamadıklarını belirtmiştir. Buna göre kentsel dönüşüm süreciyle ortaya çıkan sorunlar ele alındığında, sürecin belirsiz olmasından dolayı gelecek endişesi yarattığı $(\% 90,3)$, uzun dönem plan yapmayı engellediği $(\% 87,5)$, mahalleden ve komşulardan ayrılma düşüncesinin olumsuz etkilediği $(86,9)$ ve oturulan konutların yıkılma ihtimalinin tadilat yapmayı engellediği $(\% 77,2)$ görülmektedir. Dolayısıyla yapılan araştırma sonucunda ortaya çıkan bu sorunlar görüşülenlerin kentsel dönüşümü destekleme davranışlarını etkilediği söylenebilir.

Kentsel dönüşüm süreçlerinin Derbent Mahallesinde hali hazırda yarattığı sorunların dışında, kentsel dönüşümün gerçekleşmesinin gelecekte ne gibi ekonomik ve sosyal sorunlar ortaya çıkarabileceği ve Derbent Mahallesi halkının bu konudaki görüşleri tespit edilmiştir. Buna göre, görüşülenlerin Derbent mahallesinde kentsel dönüşüm projesinin uygulamaya konması halinde ortaya çıkabilecek olası durumlarla ilgili olarak görüşülenlerin yaklaşı \%79'u mahalleden ayrılmaları, \%87'si ise borçlandırılarak ev sahibi olmaları olmaları sonucunda ekonomik bakımdan zorlanacaklarını ifade etmiştir. İçli' in yaptığı bir çalışmada (2011: 53) da görüşülenlerin tamamına yakını kentsel dönüşüm sonucunda yapılan toplu konutlara taşınmalarıyla birlikte ekonomik bakımdan zorlandıklarını belirtmiştir. Ayrıca örneklem grubunun yaklaşık \%71'i bir apartman dairesinin masraflarını karşılayamayacaklarını, \%84'ü ise projenin öngörülen konutların yapılmasıyla ililşkili olarak yapılan yeni konutların değeri artacağından mevcut durumda kiracı olanların kira bedellerini ödeme bakımından ekonomik olarak zorlanacaklarını belirtmişlerdir.

Kentsel dönüşümün toplumsal sonuçları ele alındığında örneklem grubunun yaklaşık \%84'ü kentsel dönüşüm sonrasında mahallede komşuluk ilişkilerinin bozulacağını, \%85'i ise mahalledeki eski güven ve birlik duygusunun kaybolacağını ifade etmiştir. Kentsel dönüşüm projesinin uygulanmasından sonraki süreçte mahalle halkının, mahalle dışından gelen insanlarla aynı yaşam alanlarını paylaşmak durumunda kalacağı düşüncesi, örneklem grubunu endişelendirmektedir. Buna göre görüşülenlerin yaklaşık \%62'si farklı toplumsal sinıfa ailt insanlarla birarada yaşamanın problem yaratacağını, \%55'i ise apartman yaşamına uyum sağlamakta zorlanacaklarını ifade etmektedir. Özellikle bahçeler, parklar ve sokaklar mahalle halkının aile ve komşuları ile en önemli sosyalleşme alanlarıdır. $\mathrm{Bu}$ sebeple görülüşülenlerin apartman yaşamına sıcak bakmadıklarını, hemşerilik ve akrabalık bağlarının güçlü olması ile 
karakterize edilebilcek olan mahalle kültürünün bozulmasını istemediklerini sıklıkla dile getirmektedirler. Nitekim yapılan bir çalışmada da kentsel dönüşüm süreci sonucunda mahallenin yeniden yapılandırılmasıyla birlikte mekânsal olarak bir değişmin yanında eski mahalle yapısının da değiştiğini ve bu durumun komşuluk ilişkilerini olumsuz etkilediğini belirtilmektedir (Hardal ve Kılıç, 2019: 707).

Derbent Mahallesi halkının yaklaşık \%85'i yaşadıkları mahalle için geçmişte tasarlanan kentsel dönüşüm projesine benzer bir projeyle tekrar karşılaşmaları halinde onaylamayacaklarını belirtmiştir. Geçmişteki projeye destek davranışı ile yine böyle bir kentsel dönüşüm projesiyle karşı karşıya kalmaları durumunda görüşülenlerin tutumlarının ne olacağ1 arasında $[\mathrm{x} 2(4)=163.377$, $\mathrm{p}<0,05]$ anlamlı bir ilişki saptanmıştır. Buna göre, bir önceki proje planına destek vermeyen görüşülenlerin yaklaşık \%90'1 tekrar böyle bir projeye destek vermeyeceklerin, geçmişte destek verenlerin yaklaşık \%50'si ise yeniden destekleyebileceklerini belirtmiştir. Bu doğrultuda daha önce yapılması planlanan kentsel dönüşüm sürecine olumsuz görüş bildiren örneklem grubunun tekrar böyle bir projeyle karşılaşmaları durumuda projeye destek vermeyeceklerini ifade etmiştir. Bunun nedenleri arasında gelecek kaygısı, uzun dönem plan yapamama ve mahalleden ayrilma korkusunun yer aldığı söylenebilir.

Örneklem grubunun kentsel dönüşüm sürecinde ortaya çıkan gelecek endişesi göz önünde bulundurulduğunda ise mahalle ile ilgili öncelik verilmesi gereken konular arasında "arazilerin mahalle sakinlerine devredilmesi" $(\% 64,4)$, "mahalle sakinlerinin beklentilerinin de göz önüne alındı̆̆ bir dönüşümün gerçekleştirilmesi” (\%28,3) yer almaktadır. Buna göre özellikle kentsel dönüşümle ilgili çalışmaların yürütülmesi amacıyla mahalle kooperatifinin kurularak, çalışmaların örgütlü şekilde devam ettirilmesi gerekmektedir. Böylelikle de mahalle halkının sıklıkla dile getirdiği arazilerin kendilerine devredilmesi ve mahallenin sosyal dokusuna zarar vermemesi konusunda halkın talep ve beklentilerinin göz önünde bulundurularak yerinde bir dönüşümün gerçekleştirilmesi sağlanabilir.

\section{Sonuç}

Kentlerin sağliksız ve plansız bir şekilde büyümesi sonucu gecekondulaşma süreciyle birlikte ortaya çıkan altyapı ve sosyo-ekonomik sorunlar kentsel dönüşüm projeleri yardımıyla kentsel alanda yenilemeye gidilmekte, gecekondu alanlarında yaşayan insanların yaşam şartları iyileştirilmeye çalışılmaktadır. Ancak uygulanması planlanan projeler kapsamında hem kentin sorunlarını azaltmak hem de yaşanabilir bir kent sunma isteği ön plana çıksa da bu projeler beraberinde birçok soruna da yol açmaktadır.

$\mathrm{Bu}$ çalışmada kentsel dönüşümün toplumsal boyutu üzerinde durulmakta, kentsel dönüşüm uygulanması planlanan gecekondu mahallelerinde yaşayan bireylerin karşılaştıkları sorunlar ve bunun yaşamlarına nasıl yansıdığının ortaya konulması amaçlanmaktadır. Buna göre çalışmada Derbent Mahallesi'nde yaşayan halkın mahalleleriyle ilgili gündeme getirilmiş olan kentsel dönüşüm projesiyle ilişkili ortaya çıkan sorunlar ve bu sorunların toplumsal yansımaları tespit edilmeye çalışılmaktadır.

Alan verileri doğrultusunda çalışma ele alındığında örneklem grubunun kentsel dönüşüme olumsuz bir anlam yüklediği görülmektedir. Görüşülenler, kentsel dönüşümü ifade ederken öncelikle rant, yoksul bölgelerin ortadan kaldırılmasıyla yoksul ve varlıklı kesimler arasındaki eşitsizliğin daha da artması gibi konulara vurgu yapmaktadırlar. Ayrıca görüşülenler kentsel dönüşümle birlikte bir yandan konutlarının yenilenmesi, yeni yaşam alanlarına sahip olma ve yaşam strandardının yükselmesi gibi olumlu görüşlere sahipken; diğer yandan mahalle kültürünün ve komşuluk ilişkilerinin zarar görmesi konusunda endişe duymaktadırlar

Mahalle halkının yarısı Derbent mahallesinde bir kentsel dönüşümü gerekli görmektedir. Buna göre kentsel dönüşüme destek davranışı demografik özelliklere, konut özelliklerine ve halkın mahalledeki dayanışma ağlarına ilişkin fikirlerine göre farklılaşmaktadır. Gençlerin orta yaşlı ve 
yaşlılara göre, erkeklerin kadınlara göre, kiracıların ev sahiplerine göre, apartmanda yaşamak isteyenlerin müstakil evde yaşamak isteyenlere göre, mahallede yaşamaktan memnun olmayanların memnun olanlara göre, komşuluk ilişkilerinin kötü olduğunu düşünenlerin iyi olduğunu düşünenlere göre kentsel dönüşümü onaylama eğilimi daha yüksektir.

Derbent mahallesi halkı kentsel dönüşüm sürecinde yapılması öngörülen projelerin mevcut haliyle mahalleye ve mahalleliye kötü bir gelecek sunacağından endişe duymaktadır. Yaşadıkları mahalle ile ilgili olarak yapılması planlanan kentsel dönüşüm projesine benzer bir projeyle yeniden karşılaşmaları durumunda bu projeye de onay vermeyecekleri saptanmıştır. Ayrıca görüşülenlerin kentsel dönüşümle ilişkili kendi deneyimleri özelinde yaşadıkları sorunların da etkisiyle "kentsel dönüşüm" kavramıyla ilgili tepkisel bir noktaya gelmişlerdir. Nitekim alan verilerinden elde edilen bilgiler ve araştırma sırasında yapılan gözlemlere göre, mahalle halkının kentsel dönüşüm fikrinin kendisinden çok kentsel dönüşümün uygulanma biçimlerine karşı çıktığı anlaşılmaktadır. Dolayısıyla Derbent Mahallesi halkı, kentsel dönüşüm sürecinde kendi beklentilerinin de göz önünde bulundurulduğu ve mahalleden ayrılmalarını gerektirmeyen bir "yerinde dönüşüm" talebini dile getirmektedir. Buna göre kentsel dönüşüm politikaları ve uygulanması planlanan projelerin tasarlanmasında halkın beklentilerinin daha iyi analiz edilmesi gerekliliği ortaya çıkmaktadır.

Kentsel dönüşümün sonuçlarına ilişkin elde edilen verilere göre; belirsizlik ile şekillenen kentsel dönüşüm süreci hâlihazırda,

1. Gelecek endişesi yaratmaktadır.

2. Örneklem grubunun mevcut yaşam alanları ve konutlarıly ilgili uzun vadeli plan yapmasını engellemekle beraber evlerin bir gün yıkılabileceği ihtimalinin söz konusu olması tadilat gibi değişiklikler yapılmasını engellemektedir.

4. Mahalle ve komşulardan ayrılma korkusu ile birlikte mahalle kültürünün yok olması, mevcut olan toplumsal bağların çözülmesi tehlikesini barındırmaktadır.

Kentsel dönüşüm süreçlerinin Derbent Mahallesinde hali hazırda yarattığı sorunların dışında, gelecekte ortaya çıkarabileceği ekonomik ve sosyal sorunlar ele alındığında ise;

1. Derbent Mahallesi halkı kentsel dönüşümün hayata geçmesi halinde mahalleden ayrılma konusuna sıcak bakmamakta, böyle bir durumda ekonomik problem yaşayacaklarını belirtmektedir.

2. Kentsel dönüşüm projelerinde uygulanan borçlandırarak ev sahibi edilme durumunda, bu konutların taksitlerini ödeyemeyeceklerini ve ekonomik olarak sorun yaşayacaklarını ifade etmektedir.

3. Dönüşüm sonrası apartman dairesinde yaşamanın hem sosyal hem ekonomik sonuçları Derbent Mahallesi halkı tarafından onaylanmamaktadır.

4. Kentsel dönüşümün gerçekleşmesinin eski güven ve birlik duygusuna zarar vereceği düşünülmektedir.

5. Derbent Mahallesi halkı, kentsel dönüşüm sonrası farklı sosyal sınıf ve kültürden insanlarla birlikte yaşamak istememektedir.

6. Kentsel dönüşüm sonrası kiracıların ekonomik anlamda mağdur olacağı düşüncesi yer almaktadir.

Sonuç olarak kentsel dönüşüm süreci Derbent Mahallesi halkını ekonomik ve sosyokültürel anlamda olumsuz etkilemekte ve bu süreçte yaşanan toplumsal sorunlar, mahalle halkının kentsel dönüşümü destekleme davranışını farklılaştırmaktadır. 


\section{Kaynakça}

Alver, Z. D. (2010). Türkiye'de kentsel dönüşüm uygulamalarında kente intibak sorunu [Yayımlanmamış yüksek lisans tezi]. Gazi Üniversitesi Sosyal Bilimler Enstitüsü.

Ataöv, A., Osmay, S. (2007). Türkiye'de kentsel dönüşüme yöntemsel bir yaklaşım. ODTü Mimarlık Fakültesi Dergisi, (2), 66-72.

Aydın, S. (2007). Kentleşme ve konut politikaları açısından neo-liberalizmin eleştirel bir değerlendirmesi ve sosyal adalet fikrinin yeniden inşaası, Sosyoloji Araştırmaları Dergisi, (1), 28-56.

Beyazıt, E., Gül, H., Güneş, M. (2013). Kent kimliği ve kimliksizleştirilen kentler üzerine bir tartışma, Kent Üzerine Özgür Yazılar, C. Ergun, M. Güneş, A. Dericioğulları Ergun (Ed.), Bağlam Yayıncılık, 149-162.

Es, M., Ateş, H. (2004). Kent yönetimi, kentlileşme ve göç: sorunlar ve çözüm önerileri. Sosyal Siyaset Konferanslart Dergisi, (48), 208-209.

Erman, T. (1998). Farklılaşan kırsal kökenli cemaat, değişen gecekondu: bir etnografik araştırmanın gösterdikleri. Sosyoloji Araştırmaları Dergisi, 1(1), 49-59.

Firidin Özgür, E. (2006). Sosyal ve mekânsal ayrışma çerçevesinde yeni konutlaşma eğilimleri: kapalı siteler, İstanbul, Çekmeköy örneği, Planlama, (4), 79-95.

Girit Mcdaniel, G. (2010). Kentsel dönüşüm politikalarının küreselleşme çerçevesinde değerlendirilmesi: Sulukule örneği [Yayımlanmamış yüksek lisans tezi]. Marmara Üniversitesi Sosyal Bilimler Enstitüsü.

Güneş, S. (2014). Kentsel dönüşümde kentsel haklar ve soylulaştırma: İstanbul Şerifali Çiftliği bölgesi imar iskân evlerinde yapılan niteliksel bir araştırma [Yayımlanmamış yüksek lisans tezi]. Maltepe Üniversitesi Sosyal Bilimler Enstitüsü.

Güngör Ergan, N. ve Kütük, Ş. (2007). Kentsel dönüşüm projesi kapsamındaki Hacılar Mahallesinde yaşayanların bu projeye bakışları. Edebiyat Fakültesi Dergisi, 24 (1), 83-106.

Görgülü, Z. (2009). Kentsel dönüşüm ve ülkemiz. TMMOB İzmir Kent Sempozyumu.

Hardal, S., K1lıç, T. (2019). İstanbul Gaziosmanpaşa' da tamamlanan kentsel dönüşüm projelerinin sosyo-mekânsal etkileri. Sosyal Bilimler Araştırmaları Dergisi, 14 (2), 699-716.

İçli, G. (2011). Kentsel dönüşüme ilişkin sosyolojik bir değerlendirme: Denizli örneği. Sosyal ve Beşeri Bilimler Dergisi, 3(1), 43-57.

Keleş, R. (1978). 100 soruda Türkiye'de kentleşme, konut ve gecekondu. Gerçek Yayınevi.

Keleş, R. (1996). Kentleşme politikası. İmge Kitabevi Yayınları.

Kıray, M. (1964). Ereğli: ă̆ır sanayiden önce bir sahil kasabası. İletişim Yayınları.

Kıray, M. (1998). Kentleşme yazıları. Bağlam Yayınları.

Koyuncu, A. (2012). Türkiye'de göç ve kentleşme. Kent Sosyolojisi, K. Alver (Ed. ). Hece Yayınları, 379-393.

Mutlu, S. (2007). Türkiye'de yaşanan gecekondulaşma süreci ve çözüm arayışları: Ankara örneği [Yayımlanmamış yüksek lisans tezi]. Ankara Üniversitesi Sosyal Bilimler Enstitüsü.

Öngören, G. ve Çolak, İ. (2013). Kentsel dönüşüm hukuku. Öngören Hukuk Yayınları.

Özden, P. (2008). Kentsel yenileme. İmge Yayınevi. 
Özden, P.P. (2010). Kentsel yenilemenin unutulan öğesi: toplumsal yenileme. Türkiye Perspektifinden Kent Sosyolojisi Çalışmaları, Ö. Uğurlu, N. Ş. Pınarığlu, A. Kanbak ve M. Şiriner (Ed. ). Örgün Yayınevi, 267-309.

Özer, İ. (2004). Kentleşme, kentlileşme ve kentsel değişme, Ekin Kitabevi.

Sağlam, S. (2006). Türkiye'de iç göç olgusu ve kentleşme. Hacettepe Üniversitesi Türkiyat Araştırmalart, 5, 33-44.

Tekeli, İ. (2008). Göç ve ötesi. Tarih Vakfı Yurt Yayınları.

Türk Dil Kurumu (2020). http://tdk.gov.tr/

Türkdoğan, O. (2006). İstanbul gecekondu kimliği. IQ Kültür Sanat Yayıncılık.

Türkdoğan, O. (1989). Bilimsel değerlendirme ve araştırma metodolojisi. Milli Eğitim Bakanlığı Yayınları.

Y1ldız, M. Z., Zümrüt, M. S. (2012). Toplu konut idaresi (TOKİ)'nin kentsel dönüşüme etkisi ve konut üretim faaliyetlerine eleştirel bir bakış (Diyarbakır Kenti örneği). Kent Sosyolojisi, K. Alver (Ed. ). Hece Yayınları, 395-434.

Yılmaz, E. (2016). Konut sorunu ve toplu konut üretiminde TOKI'nin ve belediyelerin rolü. Gazi Üniversitesi Sosyal Bilimler Dergisi, 3 (7), 31-50.

Yücel, H., Aksümer, G. (2011). Kentsel dönüşüme karşı kent hakkı mücadelesi: Kazımkarabekir Mahallesi'nde mekansal kimlik ve dayanışma örüntüleri. Eğitim Bilim Toplum Dergisi, 9 (36), 117-139.

12362 Say1l Resmi Gazete. (1966). 775 numaral gecekondu kanunu. https://www.mevzuat.gov.tr/MevzuatMetin/1.5.775.pdf, 19.05.2020. 